\title{
The Inheritance of Diabetes in the Chinese Hamster
}

\author{
L. BUTLER
}

Department of Zoology, University of Toronto

Summary: 1. The pedigrees and Tes-tape scores of over 6000 hamsters in the Best colony in Toronto and the Upjohn Colony in Kalamazoo were examined. It was found that the distribution of Tes-tape scores in the Best colony was $23 \%+, 6 \%++, 3 \%+++$, and $5 \%++++$. The incidence of diabetes rose for the first eleven generations of inbreeding then fell off slightly. In the Upjohn colony, which had a higher incidence of diabetes, the litter sizes were smaller and the pre-weaning deaths greater. When one or both of the parents were diabetic $40 \%$ of the young died as opposed to $14 \%$ for other matings. Non-diabetic parents produced slightly less diabetics and significantly less trace animals than did any other type of mating. 2. It was concluded that diabetes is inherited but that no simple system of inheritance will fit the data. A polygenic system is postulated with a minimum of four genes any two of which when homozygus recessive will cause diabetes. Because of the variety of the quadruple recessive and the lower viability of diabetics, the mating diabetic $\mathrm{x}$ diabetic will breed true one mating in six. - 3. The polygenes act on various physiological systems and not on a "dormant" diabetic gene. The diabetic syndrome is the result of the action of these genes on enzyme production, cell proliferation, membrane permeability, and general metabolism, in various parts of the body. Thus one would not expect all diabetic hamsters to exhibit retinopathy or hydronephrosis, but one would expect predominantly the same manifestations within the same subline.

La transmission héréditaire du diabète chez le hamster chinois.

Résumé. 1. Nous avons analysé les pedigrees et les estimations de glucosurie (Tes-Tape) de plus de 6000 hamsters chinois de la colonie du Best Institute à Toronto et de celle de la maison Upjohn à Kalamazoo. A Toronto, la distribution des estimations au Tes-Tape était de $23 \%+$, de $6 \%++, 3 \%+++$, et de $5 \%++++$. L'incidence du diabète a augmenté durant les 11 premières générations de consanguinité, elle a légèrement diminué par la suite L'incidence du diabète est plus grande dans la colonie Upjohn, les nichées étant plus petites et le nombre des morts avant sevrage plus grand. Lorsqu'un ou deux parents sont diabétiques, $40 \%$ des rejetons ne survivent pas; $14 \%$ seulement, lorsque les deux parents ne sont pas diabétiques. Par rapport à tout autre type d'accouplement, les parents non-diabétiques donnent naissance à un nombro légèrement moindre de diabétiques et nettement moindre d'animaux à faible glucosurie. - 2. Nous concluons de ces données que le diabète du hamster chinois est héréditaire mais qu'aucun système simple de transmission n'est à même de cadrer avec elles. C'est pour. quoi nous proposons un système composé d'un minimum de 4 gènes dont la coïncidence de deux en homozygocité récessive mène à un diabète patent. Le nombre des possibilités données par un système récessif quadruple associé à la moindre capacité de survie des diabétiques permet de prévoir que le croisement diabétique $\mathrm{x}$ diabétique ne produira des diabétiques qu' une fois sur 6. - 3. Les polygènes agissent sur divers systèmes physiologiques et non pas sur un gène diabétique "caché«. Le syndrome diabétique est le résultat de l'action de ces gènes sur la production d'enzymes, la prolifération des cellules, la perméabilité des membranes et le métabolisme de différents tissus. Aussi nous ne devrions pas nous attendre à ce que tous les hamsters diabétiques se ressemblent et soient caractérisés, par exemple, par une rétinopathie ou une hydronéphrose, mais une plus grande fréquence de manifestations semblables est probable pour chaque lignée.

Die Vererbung des Diabetes beim chinesischen Hamster.

Zusammenfassung. 1. Von über 6000 Hamstern der Kolonie des Best Instituts in Toronto und der UpjohnKolonie in Kalamazoo wurden die Stammbäume und TesTape-Ergebnisse geprüft. Dabei ergab sich, daß in der Best'schen Kolonie mit Tes-Tape $23 \%+, 6 \%++$, $3 \%+++$ und $5 \%++++$ reagierten. Während der ersten 11 Generationen Inzucht stieg das Vorkommen von Diabetes an und fiel danach leicht ab. In der UpjohnKolonie, wo das Auftreten von Diabetes häufiger war, waren die Würfe kleiner und die Sterbeziffer unter den noch nicht entwöhnten Jungen höher. Wenn einer oder beide Elternteile diabetisch waren, starben $40 \%$ der Jungen im Gegenteil zu 14\% bei anderen Paaren. Normale Eltern hatten im allgemeinen weniger diabetische Junge, und die Zahl der Tiere, die nur Spuren Glucose im Urin aufwiesen, war wesentlich geringer als bei anderen Paarungstypen. - 2. Dareus wurde geschlossen, daß Diabetes beim chinesischen Hamster zwar erblich ist, daß die Ergebnisse aber nicht in ein einfaches Vererbungsschema einzugliedern sind. Es wird ein polygenetisches System vorgeschlagen, mit mindestens 4 Genen, von denen jeweils die Homozygotie von zwei Diabetes hervorruft. Wegen der Möglichkeiten, die sich aus den 4 rezessiven Genen ergeben, sowie wegen der geringeren Überlebenskraft der zu Diabetes Prädisponierten, erzeugt eine Paarung von 2 Diabetikern nur in einem Fall von sechs ebenfalls einen Diabetes. - 3. Die Polygene wirken auf verschiedene physiologische Systeme und nicht auf ein ,ruhendes“ diabetisches Gen. Das diabetische Syndrom ist das Ergebnis der Wirkung dieser Gene auf Enzymproduktion. Zellwachstum, Membrandurchlässigkeit und allgemeinen Stoffwechsel in den verschiedenen Geweben. Daher ist nicht zu erwarten, daß alle diabetische Hamster Retinopathie oder Hydronephrose aufweisen, jedoch ist zu erwarten, daß die gleichen Erscheinungsmerkmale innerhalb eines Zuchtstammes gehäuft auftreten.

Key-words: Spontaneous diabetes, Chinese hamster, Cricetulus griseus, Inheritance of diabetes, Genetics of diabetes, Polygenic system of inheritance.
The pioneer work on the inheritance of diabetes in the Chinese hamster (Cricetulus griseus) was done by Yergantar 1964. He considered diabetes to be caused by the recessive genes $d d$ plus homozygous modifiers. YERGANIAN found that the simple methods of inheritance such as monogenic recessive or incomplete dominant would not fit the data, therefore he suggested "the participation of modifier genes which, in turn, must reach a particular level of homozygosity before "activating" diabetic gene(s)." He found that diabetes flourished during the course of inbreeding but was scarce or absent in the $\mathrm{F}_{1}, \mathrm{~F}_{2}$, and $\mathrm{F}_{3}$ of hybrid lines. In his JBY family he gives a sub-line pedigree in which three matings of normal animals, from the 
fourth generation of inbreeding, produce 15 normal and 31 diabetics in the next four generations. A few generations after this the line became free of diabetics. The pedigree of the BUY line, which had a lower percentage $(3.8 \%)$ of diabetics, gives good evidence that the same proportion of diabeties is produced by normal parents as by diabetic ones. After ten or more generations of inbreeding the proportion of diabetics drops to almost zero. YERGANIAN points out that "were it not for the appearance of new diabetics following hybridization and inbreeding, for four to five generations, the diabetic syndrome would have been lost long before now."

As further breeding records became available it was evident that the mode of inheritance should be re-examined. The breeding records of the Best colony in Toronto and the Upjohn colony in Kalamazoo these will segregate and there will be two or three different classes of individuals. The assignation of animals to different segregant classes will depend on the test used and on the environmental experience of the animal being tested. When the expression of the gene depends greatly on environmental factors, the animal may possess the gene but not show the character. This is called reduced penetrance, and the proportion of the genotype that shows the character is given as the percentage penetrance of the gene.

To distinguish between alternative theories of inheritance the Geneticist would like all animals classified by a rigid test that would divide them into two or more definite classes. The only widely used test is the Tes-tape method of assessing urinary glucose, which in spite of its shortcomings will serve as our criterion of a diabetic animal. In both colonies the +

Table 1. Testape scores by generation and sex for the Banting-Best colony

\begin{tabular}{|c|c|c|c|c|c|c|c|c|}
\hline \multicolumn{2}{|c|}{ Generation } & \multirow{2}{*}{+} & \multirow{2}{*}{$\begin{array}{l}++ \\
-\end{array}$} & \multirow{2}{*}{$\frac{+++}{-}$} & \multirow{2}{*}{$\frac{t+++}{2}$} & \multirow{2}{*}{$\frac{\text { TotaI }}{30}$} & \multicolumn{2}{|c|}{$\begin{array}{ll}\text { Percentage } \\
+ \\
+\end{array}$} \\
\hline 1 & & & & & & & - & 6.7 \\
\hline 2 & $\begin{array}{l}x \\
0 \\
0\end{array}$ & $\begin{array}{l}2 \\
1\end{array}$ & $\begin{array}{l}4 \\
1\end{array}$ & $\begin{array}{l}1 \\
-\end{array}$ & $\begin{array}{c}1 \\
-\end{array}$ & $\begin{array}{l}58 \\
58\end{array}$ & $\begin{array}{l}3.4 \\
1.7\end{array}$ & $\begin{array}{r}10.4 \\
1.7\end{array}$ \\
\hline 3 & $\begin{array}{l}x \\
0 \\
0\end{array}$ & $\begin{array}{l}1 \\
1\end{array}$ & $\begin{array}{l}1 \\
2\end{array}$ & - & $\begin{array}{l}4 \\
4\end{array}$ & $\begin{array}{l}83 \\
90\end{array}$ & $\begin{array}{l}1.2 \\
1.1\end{array}$ & $\begin{array}{l}6.0 \\
6.7\end{array}$ \\
\hline 4 & $\begin{array}{l}0 \\
0 \\
0\end{array}$ & $\begin{array}{l}2 \\
1\end{array}$ & $\overline{3}$ & $\frac{1}{-}$ & $\begin{array}{l}7 \\
5\end{array}$ & $\begin{array}{l}96 \\
94\end{array}$ & $\begin{array}{l}2.0 \\
1.0\end{array}$ & $\begin{array}{l}8.4 \\
8.5\end{array}$ \\
\hline 5 & $\begin{array}{l}\hat{0} \\
\text { O⿱一土 }\end{array}$ & $\begin{array}{l}1 \\
6\end{array}$ & $\begin{array}{l}3 \\
6\end{array}$ & $\begin{array}{l}2 \\
2\end{array}$ & $\begin{array}{l}8 \\
1\end{array}$ & $\begin{array}{l}99 \\
89\end{array}$ & $\begin{array}{l}1.0 \\
6.8\end{array}$ & $\begin{array}{l}13.0 \\
10.0\end{array}$ \\
\hline 6 & $\begin{array}{l}0 \\
0 \\
0\end{array}$ & $\begin{array}{r}9 \\
11\end{array}$ & $\begin{array}{l}4 \\
2\end{array}$ & $\begin{array}{c}2 \\
-\end{array}$ & $\begin{array}{l}1 \\
3\end{array}$ & $\begin{array}{l}74 \\
76\end{array}$ & $\begin{array}{l}12.2 \\
14.5\end{array}$ & $\begin{array}{l}9.5 \\
6.6\end{array}$ \\
\hline 7 & $\begin{array}{l}0 \\
0 \\
0\end{array}$ & $\begin{array}{l}23 \\
24\end{array}$ & $\begin{array}{l}4 \\
3\end{array}$ & $\begin{array}{l}5 \\
4\end{array}$ & $\begin{array}{l}3 \\
5\end{array}$ & $\begin{array}{l}64 \\
74\end{array}$ & $\begin{array}{l}36.0 \\
32.5\end{array}$ & $\begin{array}{l}18.8 \\
16.3\end{array}$ \\
\hline 8 & $\begin{array}{l}\hat{O} \\
0 \\
+\end{array}$ & $\begin{array}{l}39 \\
45\end{array}$ & $\begin{array}{r}12 \\
6\end{array}$ & -1 & $\begin{array}{l}4 \\
7\end{array}$ & $\begin{array}{l}75 \\
93\end{array}$ & $\begin{array}{l}52.0 \\
48.8\end{array}$ & $\begin{array}{l}21.4 \\
15.0\end{array}$ \\
\hline 9 & $\begin{array}{l}0 \\
0 \\
9\end{array}$ & $\begin{array}{l}61 \\
58\end{array}$ & $\begin{array}{l}7 \\
8\end{array}$ & $\begin{array}{l}3 \\
3\end{array}$ & $\begin{array}{l}8 \\
7\end{array}$ & $\begin{array}{l}105 \\
137\end{array}$ & $\begin{array}{l}58.0 \\
42.4\end{array}$ & $\begin{array}{l}17.1 \\
13.2\end{array}$ \\
\hline 10 & ô & $\begin{array}{l}54 \\
57\end{array}$ & $\begin{array}{r}8 \\
16\end{array}$ & $\begin{array}{l}4 \\
5\end{array}$ & $\begin{array}{l}10 \\
10\end{array}$ & $\begin{array}{l}113 \\
152\end{array}$ & $\begin{array}{l}47.8 \\
37.5\end{array}$ & $\begin{array}{l}19.5 \\
20.4\end{array}$ \\
\hline 11 & $\begin{array}{l}\hat{o} \\
0\end{array}$ & $\begin{array}{l}42 \\
37\end{array}$ & $\begin{array}{r}4 \\
13\end{array}$ & $\begin{array}{r}14 \\
4\end{array}$ & $\begin{array}{l}1 \\
9\end{array}$ & $\begin{array}{l}116 \\
135\end{array}$ & $\begin{array}{l}36.2 \\
27.5\end{array}$ & $\begin{array}{l}16.4 \\
19.3\end{array}$ \\
\hline 12 & 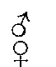 & $\begin{array}{l}17 \\
21\end{array}$ & $\begin{array}{r}13 \\
4\end{array}$ & $\begin{array}{l}5 \\
7\end{array}$ & $\begin{array}{l}3 \\
4\end{array}$ & $\begin{array}{l}106 \\
111\end{array}$ & $\begin{array}{l}16.0 \\
19.0\end{array}$ & $\begin{array}{c}19.9 \\
13.6\end{array}$ \\
\hline 13 & $\begin{array}{l}0 \\
0 \\
9\end{array}$ & $\begin{array}{l}8 \\
8\end{array}$ & $\begin{array}{l}2 \\
2\end{array}$ & - & $\begin{array}{l}1 \\
-\end{array}$ & $\begin{array}{l}62 \\
66\end{array}$ & $\begin{array}{l}11.2 \\
12.1\end{array}$ & $\begin{array}{l}4.5 \\
9.1\end{array}$ \\
\hline Tot & & 529 & 128 & 67 & 108 & 2261 & 23.3 & 13.1 \\
\hline
\end{tabular}

were used for this purpose. These records contain the histories of over 6000 animals. Before they can be utilized it is necessary to clarify our concepts of diabetic classification and modes of heredity. We need to know whether the potentiality to become diabetic is inherited. The complex interplay between heredity and environment makes it difficult to characterize a disease such as this as hereditary or physiological. If all hamsters have genes for predisposition to diabetes, and the environmental stresses in any period from intra-uterine to senescence may bring about its onset, then diabetes is not inherited. If there is a gene or genes that exist in alternate states or alleles, then reading is the least consistent, alternating between normal and + with an infrequent reading of +++ . For the purpose of genetic analysis it seems advisable to keep these + animals in a separate category from the normal or the,+++++ , and ++++ ones. Therefore hamsters with a Tes-tape ${ }^{\circledR}$ reading of + will be classified as trace ( $\mathrm{T}$ ) animals, and the others with positive readings will be listed as diabetic (D) as contrasted with the hamsters with consistent negative readings, which will be classified as normal (N).

The Tes-tape ${ }^{\circledR}$ data for the Best colony from the foundation stock of 30 obtained from YERGANIAN to the incomplete generation $\mathbf{1 3}$ are given in Table 1 . In 
the first four generations inbreeding was relatively mild, but after that most matings were brother $x$ sister or father $\times$ daughter. Of the total of 2261 animals, $23 \%$ were,$+ 6 \%$ were $t+, 3 \%$ were $t++$, and $5 \%$ were ++++ . The two sexes were evenly distributed in the four classes but in the non-diabetics there was an excess of females the sex ratio being 645:754 which is highly significant $\left(x^{2} 8.6, \mathrm{P} .001\right)$. This disturbance in the sex ratio began in generation 8 and continued through generation 11, becoming normal in the next generation. No explanation is available for this abnormal ratio. The proportion of diabetic animals stayed constant for the first four generations and then with the imposition of close inbreeding it rose rapidly until generation 10 , at which point the total diabetios and trace constituted $60 \%$, which is 6 times more than it was in the first four generations. It should be but the figures in the last column show that the litters weaned were of average size. The low productivity occurred because most females produced only one or no litters. Selection and better methods of husbandry have changed this. The litters born to diabetic females are just as large as those born to normal females. The proportion of diabetic animals does not change progressively as one moves down the mating list from $\mathrm{N} \times \mathrm{N}$ to $\mathrm{D} \times \mathrm{D}$. This could be the result of the smaller numbers of litters in the later classes. In lines $1 \& 2$ it can be seen that all crosses produce a higher proportion of diabetics than cross $\mathrm{N} \times \mathrm{N}$ does. The cross $\mathrm{D} \times \mathrm{D}$ in line 1 is excluded from this generalization as it consisted of only one litter. In line 3 the values are much more erratic, the $\mathrm{N} \times \mathrm{N}$ cross producing more diabetics than any other cross. In all 3 lines most of the hamsters come from

Table 2. The distribution of normal $(N)$. trace $(T)$, and diabetic $(D)$ hamsters in crosses made in the Banting-Best colony

\begin{tabular}{lrrrrrrr}
\hline Parents & N & \multicolumn{1}{c}{ T } & D & Total & $\%$ D & \% D + T & Mean litter \\
\hline Line 1 & & & & & & & \\
$\mathrm{N} \times \mathrm{N}$ & 236 & 92 & 14 & 342 & 4.1 & 27 & 4.2 \\
$\mathrm{~N} \times \mathrm{T}$ & 337 & 129 & 23 & 489 & 4.7 & 31 & 4.9 \\
$\mathrm{~N} \times \mathrm{D}$ & 60 & 29 & 4 & 93 & 4.3 & 36 & 4.7 \\
$\mathrm{~T} \times \mathrm{T}$ & 87 & 34 & 6 & 127 & 4.7 & 32 & 4.7 \\
$\mathrm{~T} \times \mathrm{D}$ & 14 & 8 & 1 & 23 & 4.4 & 39 & 5.7 \\
$\mathrm{D} \times \mathrm{D}$ & 3 & 2 & 0 & 5 & 0 & 40 & 5.0 \\
& 737 & 294 & 48 & 1079 & 4.4 & 31 &
\end{tabular}

$\begin{array}{lrrr}\text { Line } 2 & & & \\ \mathrm{~N} \times \mathrm{N} & 216 & 20 & 11 \\ \mathrm{~N} \times \mathrm{T} & 90 & 27 & 12 \\ \mathrm{~N} \times \mathrm{D} & 14 & 5 & 0 \\ \mathrm{~T} \times \mathrm{T} & 41 & 15 & 5 \\ \mathrm{~T} \times \mathrm{D} & 21 & 14 & 11 \\ \mathrm{D} \times \mathrm{D} & 2 & 2 & 4 \\ & 384 & 83 & 43\end{array}$

Line 3

$\begin{array}{lrrr}\mathrm{N} \times \mathrm{N} & 186 & 47 & 17 \\ \mathrm{~N} \times \mathrm{T} & 198 & 55 & 11 \\ \mathrm{~N} \times \mathrm{D} & 50 & 29 & 5 \\ \mathrm{~T} \times \mathrm{T} & 59 & 28 & 4 \\ \mathrm{~T} \times \mathrm{D} & 15 & 11 & 0 \\ \mathrm{D} \times \mathrm{D} & 0 & 0 & 0 \\ & 508 & 170 & 37\end{array}$

$\begin{array}{rrrr}247 & 4.5 & 13 & 4.7 \\ 129 & 10.6 & 30 & 4.6 \\ 19 & 0 & 26 & 4.7 \\ 61 & 8.2 & 33 & 5.1 \\ 46 & 24.0 & 54 & 5.1 \\ 8 & 50.0 & 75 & 4.0 \\ 510 & 8.5 & 25 & \end{array}$

$\begin{array}{rrrr}250 & 6.8 & 26 & 4.7 \\ 264 & 4.2 & 25 & 5.0 \\ 84 & 6.0 & 40 & 5.2 \\ 91 & 4.4 & 35 & 4.3 \\ 26 & 0 & 42 & 6.5 \\ 0 & 0 & 0 & 0 \\ 715 & 5.2 & 29 & \end{array}$

noted that most of this increase was brought about in the + category, the other three classes merely doubled. After generation 10 there was a decrease in the proportion of + animals, while the proportion of,+++++ , and ++++ animals stayed relatively constant. Thus the ratio of + to the other three classes changed from 1:6 in generation 3 to $3: 1$ in generation 9 , to $1: 1$ in generation 12 .

In Table 2 the data for the Best colony are summarized under three main lines of breeding. Actually eight lines were developed from the foundation animals but only three lines were productive, therefore the small amount of data from the poor-producing lines was added to that of the most closely related productive line. The Chinese hamster is difficult to breed,

the first two types of crosses and $x^{2}$ tests show that there is no significant difference between the proportions of each type produced by these two crosses. The use of a trace animal as a parent did not increase the proportion of diabetics, but in several cases it did increase the proportion of trace animals.

In the seventh column of table 2 is given the percentage of trace and diabetic animals combined. These figures do tend to increase progressively especially in lines 1 and 2, indicating that diabetics and trace parents do produce slightly more affected animals than do their normal counterparts. A comparision between $\mathrm{N} \times \mathrm{D}, \mathrm{T} \times \mathrm{D}$, and $\mathrm{N} \times \mathrm{N}$ shows that if one parent is diabetic it does not influence the proportion of diabetics in lines 1 and 3 but it does produce signi- 
ficantly more diabetics in line 2. In all three lines these crosses produced significantly more trace animals than did the $\mathrm{N} \times \mathrm{N}$ crosses.

The analysis of the differences between lines shows that they are highly significant with lines 2 and 3 producing a greater proportion of diabetics and a smaller proportion of trace animals than line 1. Part of this difference is the result of the different proportions of each of the six types of matings in the three lines, but since the same amount and type of selection was practised in each line, the difference is due largely to a genetic component. There were only three litters from $\mathrm{D} \times \mathrm{D}$ matings and all litters contained some normal animals.

A similar summary of three lines in the Upjohn colony is given in table 3. In the Upjohn colony the distribution of Tes-tape ${ }^{\circledR}$ scores is different from those
$\mathrm{L}$ and $\mathrm{PG}$, but not in line PA, than in the Best colony. On the other hand, the values for $D+T$ are not much higher indicating a lower percentage of trace animals. The litter sizes are smaller than in the Best colony and this may be the result of two factors. First the higher proportion of diabetics in these Upjohn lines may lead to more preweaning deaths $(41 \%$ in some lines), and secondly the females of these lines have more frequent litters than do the females of the Toronto lines. Litters born to very young mothers or fourth litters from the same female are often smaller.

There is not a clear progressive increase in either the $\mathrm{D}$ or the $\mathrm{D}+\mathrm{T}$ columns from cross $\mathrm{N} \times \mathrm{N}$ to $\mathrm{D} \times \mathrm{D}$ in any line, but a trend is evident. In line $\mathrm{L}$ a chi square test reveals that $\mathrm{D} \times \mathrm{N}$ produced more $\mathrm{T}+\mathrm{D}$ animals and significantly more $\mathrm{T}$ animals than did cross $\mathrm{N} \times \mathrm{N}$. In line $\mathrm{PG}$ the low percentage of

Table 3. The distribution of normal $(N)$, trace $(T)$ and diabetic $(D)$ hamsters in crosses made in the Upjohn colony

\begin{tabular}{|c|c|c|c|c|c|c|c|}
\hline Parents & $\mathrm{N}$ & $\mathbf{T}$ & D & Total & $\% \mathrm{D}$ & $\% \mathrm{D}+\mathrm{T}$ & Mean litter \\
\hline \multicolumn{8}{|l|}{ Line $\mathbf{L}$} \\
\hline $\mathrm{N} \times \mathrm{N}$ & 164 & 34 & 50 & 248 & 20 & 34 & 4.1 \\
\hline $\mathbf{N} \times \mathrm{T}$ & 27 & 6 & 7 & 40 & 17 & 33 & 3.6 \\
\hline $\mathbf{N} \times \mathrm{D}$ & 103 & 35 & 29 & 167 & 17 & 38 & 4.4 \\
\hline $\mathrm{T} \times \mathrm{D}$ & 35 & 5 & 6 & 46 & 13 & 24 & 3.5 \\
\hline $\mathrm{D} \times \mathrm{D}$ & 33 & 10 & 18 & 61 & 30 & 46 & 3.6 \\
\hline Total & 362 & 90 & 110 & 562 & 20 & 36 & \\
\hline \multicolumn{8}{|c|}{ Line $\mathrm{PG}$} \\
\hline $\mathbf{N} \times \mathbf{N}$ & 51 & 8 & 10 & 69 & 15 & 26 & 4.9 \\
\hline $\mathrm{N} \times \mathrm{T}$ & 7 & $\mathbf{3}$ & 2 & 12 & 17 & 42 & 4.0 \\
\hline $\mathrm{N} \times \mathrm{D}$ & 10 & 2 & 1 & 13 & 8 & 23 & 3.2 \\
\hline $\mathrm{T} \times \mathrm{D}$ & 6 & 2 & 3 & 11 & 27 & 45 & 3.7 \\
\hline \multirow[t]{2}{*}{$\mathrm{D} \times \mathbf{D}$} & 23 & 2 & 13 & 38 & 34 & 44 & 3.8 \\
\hline & 97 & 17 & 29 & 143 & 20 & 32 & . \\
\hline \multicolumn{8}{|c|}{ Line PA } \\
\hline $\mathrm{N} \times \mathrm{N}$ & 313 & 35 & 4 & 362 & 1 & 11 & 4.6 \\
\hline $\mathrm{N} \times \mathrm{T}$ & 137 & 30 & 0 & 167 & 0 & 17 & 4.4 \\
\hline $\mathrm{N} \times \mathrm{D}$ & 4 & 0 & 0 & 4 & 0 & 0 & 4.0 \\
\hline $\mathrm{T} \times \mathrm{T}$ & 9 & 2 & 0 & 11 & 0 & 2 & 3.7 \\
\hline \multicolumn{8}{|l|}{ Units } \\
\hline $\mathrm{N} \times \mathbf{N}$ & 45 & 8 & 2 & 55 & 4 & 18 & 4.2 \\
\hline $\mathrm{N} \times \mathrm{D}$ & 58 & 24 & 3 & 85 & 4 & 32 & 5.8 \\
\hline $\mathrm{D} \times \mathbf{N}$ & 44 & 5 & 3 & 52 & 6 & 16 & 4.3 \\
\hline $\mathrm{D} \times \mathrm{D}$ & 18 & 6 & 10 & 34 & 29 & 45 & 3.4 \\
\hline
\end{tabular}

of the Best colony in that while the total percentage is the same there are only half as many animals in the + class. The Upjohn tests were performed under more standard conditions and tend to show higher repeatability between successive tests on the same animals. It was also noted that the changes from generation to generation in the percentage diabetics was similar to that given for the Best colony. In the $\mathrm{L}$ line, which in the first generation had 15\%+, $7 \%++, 12 \%+++$, and $7 \%++++$, the percentage of diabetics increased slightly with each generation of inbreeding and reached a maximum of $56 \%$ in generation 6 and then fell off. It will be seen that there is a much higher percentage of diabetics in lines
$\mathrm{D}$ in the $\mathrm{N} \times \mathrm{D}$ matings may be the result of early deaths, the litter size $\mathbf{3 . 2}$ being the lowest for any mating listed in the table. The main interest in the $\mathrm{L}$ and $\mathrm{PG}$ lines is in the $\mathrm{D} \times \mathrm{D}$ matings which produced $30-34 \%$ diabetics and $10-15 \%$ trace animals. Since both these lines have a common ancestory, $P G$ began with an outcross from $\mathrm{L}$ in the $3 \mathrm{rd}$ generation, some similarity is to be expected.

In the Upjohn colony the breeding difficulties were quickly overcome, and greater selection of breeders could be practised and production units set up. These units were arranged to give the three matings $\mathrm{D} \times \mathrm{D}, \mathrm{D} \times \mathrm{N}$, and $\mathrm{N} \times \mathrm{N}$. In order to find out if the sex of the diabetic parent was important the reciprocal 
cross $\mathrm{N} \times \mathrm{D}$ was also made. The results are given in Table 3. Tests show that there was no significant difference between the percentage of diabetics produced by the reciprocal crosses, or between these crosses and the mating $\mathrm{N} \times \mathrm{N}$. There was a significant difference between the trace animals produced by the reciprocal crosses but this may represent a strain character rather than a difference due to the sex of the diabetic parent. The $\mathrm{D} \times \mathrm{N}$ matings were between $\mathrm{L} \times \mathrm{PA}$ lines whereas the $\mathrm{N} \times \mathrm{D}$ matings were all $\mathrm{L}$ strain animals. In the $\mathrm{D} \times \mathrm{D}$ unit there were 10 litters with $55 \% \mathrm{~N}: 16 \% \mathrm{~T}: 29 \% \mathrm{D}$. Thus there is a highly significant difference between the number of diabetics produced by the $\mathrm{D} \times \mathrm{D}$. matings and the number produced by any other type of mating. Examination of the birth and weaning statistics revealed that in any mating in which one or both parents were diabetic, $40 \%$ of the young died before weaning, whereas in the $\mathrm{N} \times \mathrm{N}$ matings only $14 \%$ died in this period.

\section{Mode of Inheritance}

First let us examine the question whether all hamsters possess common genes for the predisposition to diabetes, or whether these genes are segregating in the hamster stocks. If the genes are universal then the percentage incidence will depend entirely on the environment. In spite of precautions to the contrary, the environment will vary between colonies and from time to time within the same colony. The large difference in percentage incidence between the two colonies could be explained by an environmental change. Likewise the chronological increase in incidence could be attributed to the environment but it is unlikely that the environment would show a uniform change. The strains within a colony share the same environment yet have different incidences of diabetes. These differences between strains lead us to the conclusion that diabetes is hereditary, and that the chronological changes along with the difference between the two colonies, are the result of the segregation of genes.

Having conceded that there is a hereditary component, we must discover its mode of operation. Let us exclude penetrance for the present. Then since none of the three classes breed true, in fact it is impossible to say which class most nearly breeds true, we cannot use a monogenic, digenic, or polygenic scheme in which all the genes are necessary for the production of the recessive phenotype. We must adopt a scheme in which different genes can produce the same phenotype. The simplest of such schemes would be a digenic one where either $a a$ or $b b$ genotypes would produce diabetes and the diabetic animals could be of any one of five genotypes (aaBB, aaBb, aabb, AAbb, Aabb). If these genotypes existed in nearly equal frequency then 17 out of $25 \mathrm{D} \times \mathrm{D}$ matings would produce all diabetios. This is a much greater proportion of true breeding diabetics than is found, and a more complex scheme must be tried. With a trigenic scheme there are two possibilities, either $a a, b b$, or $c c$, alone is diabetic, or two genes together in combination such as aabb, aacc or bbec will be diabetic. With the first trigenic scheme 3 in 10 and with the second 25 in 49 $\mathrm{D} \times \mathrm{D}$ matings will breed true. If the former scheme were true, breeding $\mathrm{D} \times \mathrm{D}$ would give fewer pure diabetic litters, but a few generations of inbreeding should result in true breeding isolates. Since this has not happened, this scheme is unlikely. The simplest system consistent with the facts is a four gene one, in which any two genes when homozygous would bring about the diabetic state. Such a scheme could be portrayed from the physiological viewpoint as one in which each dominant allele acts through the same or a different system to produce a definite amount of insulin or insulin antagonist. Under average conditions the normal threshold is reached when the dominant alleles of any three genes are present. Trace reactions would occur when four or more recessives are present but no two genes are homozygous recessive. Some of the genotypes in each class would be:

Diabetic - aabbCCDD, aaBBccDD etc.

Trace - AaBbCcDd, aaBbCcDD, etc.

Normal - AABBCCdd, AaBbCCDD, ete

Under such a scheme it would be expected that diabetic animals with the genotypes similar to aabbecDD or aabbcedd would be less fit and would probably die early. Such early deaths would account for the fact that the percentage diabetics after rising steadily for five or six generations of inbreeding, then decreases. Another point to note about this scheme is that, whilst aabbCCDD and aaBBCCdd are both classified as diabetic by Tes-tape, bb gene may act on different cells and cellular systems than does gene dd. Under this scheme there would be $\mathbf{3 3}$ genotypes that produce a glucosuric animal and if all were equally frequent then $38 \%$ of the $\mathrm{D} \times \mathrm{D}$ matings would breed true. However, in the early stages the genotype aabbcadd will not be present, and genotypes homozygous for three recessives would be infrequent; therefore the expected $\mathrm{D} \times \mathrm{D}$ matings that would breed true are 1 in 6 . Actually in the $\mathrm{D} \times \mathrm{D}$ crosses in the $\mathrm{L}$ line we find that 3 litters in 17 were all diabetics. In each of the three cases the litters consisted of 3 or 4 young, which are insufficient numbers for a test of true breeding.

The four gene scheme was tested on two long complex pedigrees and gave a good fit in each case, but it must be pointed out that, because of the large number of possible genotypes, the scheme is quite flexible. This means that a fit does not necessarily imply that this is the actual mode of inheritance, but unless one involves penetrance, it is the simplest hypothesis which is consistent with the data. The problem could be approached through the distribution of the genes in the closed population and the effects of inbreeding on the frequency of such genes. But the fragmentation of the population and the unknown selection pressures make this method unproductive. 
It should be noted that with seven generations of brother $\times$ sister mating 0.512 of the genes should be fixed. Therefore one would expect that in each line two of the four genes would be fixed in one or other homozygous phase. Lines in which two genes were fixed in the normal phase would, with restricted breeding of the diabeties and inbreeding of all animals, quickly become a normal line. By ten generations of inbreeding 0.736 of the genes are expected to be fixed. This assumes no selection, but since we are selecting trace and diabetic animals for breeders, and diabetios breed less frequently, then the proportion of heterozygotes does not decrease as fast as expected.

The major differences between this scheme of inheritance and that proposed by YERGANIAN are:

1. No diabetic gene $d$ is postulated which is "dormant" until activated by polygenes.

2 . In the above scheme the polygenes act on various physiological systems and not on the diabetic gene. The diabetic syndrome is the result of the action of these genes on enzyme production, cell proliferation, membrane per- meability etc. in various parts of the body Thus one would not expect all diabetic hamsters to exhibit retinopathy or hydronephrosis, but one would expect predominantly the same manifestations within a subline.

3. Both schemes postulate polygenic inheritance. In Yerganian's scheme he implies that when the genetic background becomes $85 \%$ homozygous, the polygenes activating $d d$ will probably be homozygous and a diabetic animal will be produced. The above scheme, on the other hand, postulates that when a given number of genes are homozygous recessive the production of insulin will be low and diabetic symptoms may appear. The diabetics produced will have varied genotypes.

\section{References}

Yerganian, G.: Spontaneous diabetes mellitus in the Chinese hamster, Cricetulus griseus. IV. Genetic aspects. Ciba Foundation Colloquia on Endocrinology 15, 25-48 (1964).

MeIer, H., and G. Yergandan: Spontaneous diabetes mellitus in the Chinese hamster. Diabetes 10, 12-21 (1961).

Dr. LeN Butler

Department of Zoology

University of Toronto

Toronto 5, Canada 